\title{
Faktor Yang Berhubungan Dengan Penerapan Protokol Kesehatan Pada Pelaku Usaha Mikro Selama masa Pandemi Covid -19
}

\section{Factors Related to the Implementation of Health Protocols in Micro Business Actors During the Covid -19 Pandemic}

\author{
Nismawati ${ }^{1)}$, Marhtyni ${ }^{1)}$ \\ ${ }^{1)}$ Fakultas Kesehatan Masyarakat, Universitas Indonesia Timur \\ Email :nismanatsir@gmail.com /marthyninatsir@gamil.com
}

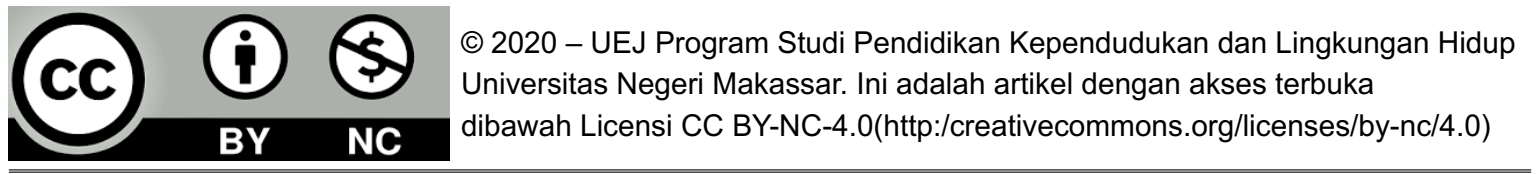

Abstrac.

The government has made various efforts to reduce the risk of Covid-19 transmission, for example by implementing social distancing and large-scale social restrictions (PSBB). Even so, there are several activities outside the home that are still ongoing, one of which is the activity of buying and selling basic household needs. Economic actors and buyers are at risk of contracting and transmitting Covid-19 so it is necessary to comply with health protocols to reduce the spread of Covid-19. This study aims to determine the factors associated with the application of health protocols to economic actors, especially micro-enterprises in running their business. This research method is analytic observational with a cross-sectional design. This research was conducted from June to August 2020. The population in this study were all micro business actors in Toddotoa Village, Pallangga District, Gowa Regency. The sample in this study amounted to 53 respondents who were taken by purposive sampling. The results showed that of 53 respondents, $43.4 \%$ applied health protocols and $56.6 \%$ did not apply health protocols. Based on the results of the analysis carried out, it can be concluded that knowledge ( $p$ $=0.001)$, attitude $(p=0.000)$, PHBS $(p=0.000)$, and infrastructure $(p=$ 0.000) are related to the application of health protocols to microentrepreneurs. The transmission of Covid-19 is so fast that it is necessary to provide education to residents regarding the causes of Covid-19 transmission, including not doing Clean and Healthy Living Behaviors (PHBS) or Washing Hands with Soap (CTPS) and environmental factors.

Key words: Health protocol, knowledge, attitude, PHBS, infrastructure

\section{ABSTRAK.}

Pemerintah telah melakukan berbagai upaya untuk mengurangi resiko penularan Covid-19 misalnya dengan menerapkan sosial distancing maupun Pembatasan Sosial Bersakala Besar (PSBB). Meskipun demikian ada beberapa kegiatan di luar rumah yang masih berjalan, salah satunya adalah kegiatan jual-beli bahan pokok kebutuhan rumah tangga. Para pelaku 
ekonomi dan pembeli berisiko tertular dan menularkan Covid-19 sehingga perlu adanya kepatuhan protokol kesehatan guna menekan penyebaran Covid-19. Penelitian ini bertujuan untuk mengetahui faktor yang berhubungan dengan penerapan protokol kesehehatan pada pelaku ekonomi khususnya usaha mikro dalam menjalankan usahanya. Metode Penelitian ini yakni observasional analitik dengan rancangan Cross-Sectional . Penelitian ini dilakukan pada bulan Juni sampai Agustus 2020. Populasi pada penelitian ini adalah seluruh pelaku usaha mikro yang berada di Desa Toddotoa Kecamatan Pallangga Kabupaten Gowa. Sampel dalam penelitian ini berjumlah 53 responden yang diambil secara purposive sampling. Hasil penelitian menunjukkan dari 53 responden terdapat 43,4\% menerapkan protokol kesehatan dan 56,6\% tidak menerapkan protokol kesehatan. Berdasarkan hasil analisis yang dilakukan maka dapat disimpulkan bahwa pengetahuan $(p=0,001)$, sikap $(p=0,000)$, PHBS $(p=0,000)$, dan sarana prasarana $(p=0,000)$ berhubungan dengan penerapan protokol kesehatan pada pelaku usaha mikro. Penulran Covid-19 ini sangat cepat sehingga perlu diadakan edukasi kepada warga terkait penyebab penularan Covid-19 diantaranya tidak melakukan Perilaku Hidup Bersih dan Sehat (PHBS) atau Cuci Tangan Pakai Sabun(CTPS) dan faktor lingkungan.

Kata kunci : Protokol kesehatan, pengetahuan, sikap, PHBS, sarana prasaran

\section{PENDAHULUAN}

Pada tanggal 30 Januari 2020, World Health Organization (WHO) menetapkan Coronavirus (COVID-19) sebagai Public Health Emergency of International Concern (PHEIC)/ Kedaruratan Kesehatan Masyarakat Yang Meresahkan Dunia (KKMMD) (CDC, 2020). Covid-19 adalah penyakit menular disebabkan oleh infeksi Severe Acute Respiratory Syndrome Coronavirus 2 (SARS-Cov-2) yang termasuk dalam keluarga besar coronavirus yang sama dengan penyebab SARS pada tahun 2003 (Penyusun, 2020b). Gejala klinis yang muncul beragam seperti gejala flu biasa (demam, batuk, pilek, nyeri tenggorokan, nyeri otot, nyeri kepala) sampai yang komplikasi berat (pneumonia atau sepsis) (Razi, P, Amani, \& Fauzia, 2020). Orang yang lebih tua, dan mereka yang memiliki masalah medis mendasar seperti penyakit kardiovaskular, diabetes, penyakit pernapasan kronis, dan kanker lebih mungkin mengembangkan penyakit serius. (WHO, 2020b). Pada saat ini, tidak ada vaksin atau perawatan khusus untuk COVID-19. Namun, ada banyak uji klinis yang sedang berlangsung mengevaluasi perawatan potensial. WHO akan terus memberikan informasi terbaru segera setelah temuan klinis tersedia (WHO, 2020a).

Kasus Covid-19 ini meningkat drastis di beberapa negara. Pada bulan maret 2020 WHO melaporkan Jumlah global total kasus COVID-19 telah melampaui 500.000 Kasus (WHO, 2020b). Pada tanggal 2 Maret 2020, Indonesia melaporkan kasus konfirmasi COVID-19 sebanyak 2 kasus. Sampai dengan tanggal 25 Maret 2020, Indonesia sudah melaporkan 790 kasus konfirmasi COVID-19 (Kemenkes, 2020b). Kasus ini terus meningkat. Di Sulawesi Selatan sendiri hingga Juni (5/6/2020) jumlah kasus Covid-19 mencapai 1.774 kasus. Peningkatan kasus ini menjadikan Provinsi Selatan berada di urutan keempat di antara 34 Provinsi di Indonesia dalam jumlah kasus Covid-19 
terbanyak (Agustina, 2020). Insiden tertinggi di Provinsi Sulawesi Selatan adalah di Kota Makassar dan diikuti dengan Kabupaten Gowa (Sulselprov, 2020) .

Kabupaten Gowa merupakan salah satu Kabupaten yang berbatasan langsung dengan ibu kota Provinsi Sulawesi Selatan (Makassar). Pada bulan mei 2020 kasus positif Covid-19 mencapai 122 kasus, dan meningkat menjadi 191 kasus positif di bulan Juni (10/6/2020). Kasus terbanyak terdapat pada Kecamatan Somba Opu dan Kecamatan Pallangga. Di Kecamatan Pallangga sendiri (30/05/2020) dari 24 kasus positif, 48 PDP, 74 ODP meningkat (10/06/2020) menjadi 28 kasus positif, 54 PDP, 81 ODP (Dinkes, 2020).

Peningkatan jumlah kasus ini menjadi kekhawatiran khususnya bagi masyarakat Desa mengingat vaksin dan obat Covid-19 ini belum ditemukan di seluruh penjuru dunia (Penyusun, 2020a) dan penyebarannya juga sangat cepat. Meskipun sudah beberapa upaya yang dilakukan oleh Pemerintah untuk mengurangi resiko penularan misalnya dengan menerapkan sosial distancing maupun Pembatasan Sosial Bersakala Besar (PSBB) akan tetapi tidak dapat dipungkiri kegiatan masyarakat di luar rumah masih tetap berjalan.

Ada beberapa masyarakat yang beresiko terpapar Covid-19. Salah satunya adalah pedagang usaha mikro yang ada di desa. Para Pedagang usaha mikro ini tetap membuka usahanya di tengah pandemik guna memenuhi kebutuhan ekonomi keluarga dan juga memenehui keperluan para konsumen. Berdasarkan pengabdian masyarakat yang telah dilakukan penulis pada bulan mei 2020 di Desa Toddotoa Kecamatan Pallangga ditemukan masih banyak pedagang yang tidak mengikuti protokol kesehatan dimana beberapa pedagang tidak memakai masker saat melakukan kegiatan jual-beli, dan beberapa warga masih ada yang berbelanja sambil berkumpul bercerita di warung tanpa ada jarak antar sesama warga. Oleh karena itu penelitian ini dilakukan untuk mengetahui faktor yang berhubungan dengan penerapan protokol kesehatan pada pelaku usaha mikro selama masa pandemi Covid-19 khususnya di Desa Toddotoa Kecamatan Pallangga Kabupaten Gowa.

\section{METODE PENELITIAN}

Penelitian ini merupakan penelitian analitik observasional dengan rancangan crosssectional. Variabel dependen pada penelitian ini yakni penerapan protokol kesehatan dan variabel independennya yakni pengetahuan, sikap, PHBS, dan sarana prasarana.

Penelitian ini akan dilaksanakan di Desa Toddotoa Kecamatan Pallangga. Kabupaten Gowa pada bulan Juni - Agustus 2020. Populasi dalam penelitian ini adalah seluruh pelaku usaha mikro yang ada di desa Toddotoa Kec. Pallangga Kab. Gowa.Teknik pengambilan sampel dilakukan dengan teknik purposive sampling yakni teknik untuk menentukan sampel penelitian dengan beberapa pertimbangan tertentu yang bertujuan agar data yang diperoleh nantinya bisa lebih representatif (Sugiono, 2016). Sampel dari penelitian ini adalah Pelaku Usaha Mikro di desa Toddotoa Kec. Pallangga Kab. Gowa yang usahanya terletak di jalan raya Pallangga yang bersedia menjadi responden.

Hal yang menjadi perhatian penulis dalam pengambilan sampel dari pelaku usaha mikro di jalan raya karena mereka lebih beresioko terpapar Covid-19 dibanding pelaku usaha mikro yang berada di lorong dusun. Letak desa ini yang berada di Jalan Poros Pallangga yang biasa dijadikan jalan alternatif menuju Kabupaten Takalar, dan Kabupaten Jeneponto memungkinkan pedagang menerima konsumen dari luar desa sehingga para pedagang juga beresiko menularkan/tertular Covid-19 dari luar wilayah. 
Adapun instrumen penelitian dalam penelitian ini adalah kuesioner. Kuesioner berisi pertanyaan yang berhubungan dengan tujuan penelitian dan membantu peneliti dalam menjawab rumusan masalah penelitian. Pertanyaan yang diberikan sesuai variabel yang diteliti. Dibagikan melalui 2 cara yakni menggunakan media online yaitu google form dan ada juga secara langsung bagi responden yang tidak memiliki hp android.

Anlaisis yang digunakan dalam penelitian ini adalah analisis univariat dan bivariat. Analisis univariat dilakukan pada setiap variabel yang diamati dari hasi penelitian agar dapat menghasilkan gambaran distribusi frekuensi dan presentase mengenai setiap variable yang diamati pada penelitian in. i. Analisis bivariat dilakukan dengan pengujian hipotesis menggunakan uji chi-square untuk mengetahui hubungan variabel pengetahuan, sikap, PHBS dan sarana presarana terhadap variabel penerapan protokol kesehatan dalam bentuk tabulasi silang (Crosstab).

\section{HASIL}

Tabel 1. Hasil Univariat Faktor Yang Berhubungan Dengan Penerapan Protokol Kesehatan Pada Pelaku Usaha Mikro Selama masa Pandemi Covid -19

VARIABEL N PRESENTASE

\begin{tabular}{lcc}
\hline Penerapan Protokol Kesehatan & 23 & 43,4 \\
Menerapkan & 30 & 56,6 \\
Tidak Menerapkan & & \\
Pengetahuan & 30 & 56.6 \\
Cukup & 23 & 43,4 \\
Kurang & 28 & 52,8 \\
Sikap & 25 & 47,2 \\
Setuju & & \\
Tidak Setuju & 19 & 35,8 \\
Perilaku Hidup Bersih \& Sehat (PHBS) & 34 & 64,2 \\
Baik & 37 & 30,2 \\
Kurang & 16 & 69,8 \\
\hline Sarana \& Prasarana & & \\
Tersedia & & \\
Tidak Tersedia & & \\
\hline
\end{tabular}




\begin{tabular}{lccc} 
& VARIABEL & N & PRESENTASE \\
\hline Jumlah & 53 & 100 \\
\hline
\end{tabular}

Sumber : Data Primer, 2020

Tabel 1 menunjukkan bahwa dari 53 Pelaku Usaha mikro terdapat penerapan protokol kesehatan sebanyak 43,4\% dan tidak menerapkan sebanyak 56,6\%. Terdapat pengetahuan cukup sebanyak $56,6 \%$ dan pengetahuan kurang sebanyak $43,4 \%$. Terdapat sikap setuju sebanyak $52,8 \%$ dan tidak setuju sebanyak $47,2 \%$. Terdapat PHBS baik sebanyak 35,8\% dan PHBS kurang sebanyak 64,2\%. Terdapat ketersediaan sarana dan prasarana, tersedia sebanyak $30,2 \%$ dan tidak tersedia sebanyak $69,8 \%$.

Tabel 2. Hasil Bivariat Faktor Yang Berhubungan Dengan Penerapan Protokol Kesehatan Pada Pelaku Usaha Mikro Selama masa Pandemi Covid -19

\begin{tabular}{|c|c|c|c|c|c|c|}
\hline \multirow{3}{*}{ Variabel } & \multicolumn{4}{|c|}{ Protokol Kesehatan } & \multirow{3}{*}{ Jumlah } & \multirow{3}{*}{$X^{2}(p)$} \\
\hline & \multicolumn{2}{|c|}{ Menerapkan } & \multicolumn{2}{|c|}{ Tidak Menerapkan } & & \\
\hline & $\mathbf{N}$ & $\%$ & $\mathbf{N}$ & $\%$ & & \\
\hline Pengetahuan & & & & & & 0,001 \\
\hline Cukup & 19 & 63,3 & 11 & 36.7 & 30 & \\
\hline Kurang & 4 & 17,4 & 19 & 82,6 & 23 & \\
\hline Sikap & & & & & & 0,000 \\
\hline Setuju & 19 & 67,9 & 9 & 32,1 & 28 & \\
\hline Tidak Setuju & 4 & 16,0 & 21 & 84,0 & 25 & \\
\hline PHBS & & & & & & 0,000 \\
\hline Baik & 18 & 94,7 & 1 & 5,3 & 19 & \\
\hline Kurang & 5 & 14,7 & 29 & 85,3 & 34 & \\
\hline Sarana \& Prasarana & & & & & & 0,000 \\
\hline Tersedia & 15 & 93,8 & 1 & 6,3 & 16 & \\
\hline Tidak Tersedia & 8 & 21,6 & 29 & 78,4 & 37 & \\
\hline
\end{tabular}

Sumber : Data Primer, 2020

Tabel 2 Menunjukkan dari 53 pelaku usaha mikro tingkat pengetahuan cukup dengan menerapkan protokol kesehatan sebanyak 63,3\% sedangkan tingkat pengetahuan kurang dengan menerapkan protokol kesehatan sebanyak 17,4\%. Hasil analisis statistis diperoleh nilai $\mathrm{p}(0,001)<0,05$ maka $\mathrm{H} 0$ ditolak. Sikap setuju dengan menerapkan protokol kesehatan sebanyak $67,9 \%$ sedangkan sikap tidak setuju dengan menerapkan protokol kesehatan sebanyak $16,0 \%$. Hasil analisis statistis diperoleh nilai p $(0,000)<$ 0,05 maka H0 ditolak. Tingkat perilaku baik dengan menerapkan protokol kesehatan sebanyak 94,7\% sedangkan tingkat pengetahuan kurang dengan menerapkan protokol kesehatan sebanyak 14,7\%. Hasil analisis statistis diperoleh nilai $\mathrm{p}(0,000)<0,05$ maka H0 ditolak. Tersedianya sarana dan prasarana dengan menerapkan protokol kesehatan sebanyak 93,8\% sedangkan tidak tersedia sarana dan prasarana dengan menerapkan 
protokol kesehatan sebanyak $21,6 \%$. Hasil analisis statistis diperoleh nilai $p(0,000)<$ 0,05 maka H0 ditolak.

\section{PEMBAHASAN}

Meskipun pemerintah telah banyak melakukan upaya pengurangan resiko penularan Covid-19, akan tetapi kasus Covid-19 tetap menunjukkan peningkatan di Indonesia. Peningkatan kasus Covid-19 mengharuskan Pemerintah untuk melakukan Pembatasan Sosial Berskala Besar (PSBB) di beberapa wilayah sehingga menimbukan beberapa masalah baru di luar sektor kesehatan seperti industri pariwisata, ekonomi dan laiinya.

Beberapa diantara pelaku usaha makro memilih untuk menutup tokonya karena kebanyakan warga beralih membeli barang dagangan melalui online tetapi untuk pelaku usaha mikro masih tetap buka dan termasuk jenis usaha yang paling tahan krisis di masa pandemi ini. Di desa pelaku usaha mikro tetap buka karena keterbatasan warga dalam pemanfaatan media online dan juga banyak warga yang lebih senang belanja langsung seperti biasanya.

Salah satu contoh usaha mikro yang ada di sekitar konsumen adalah warung kelontong. Toko kelontong termasuk usaha kecil menengah yang lebih fokus dalam menyediakan barang-barang kebutuhan rumah tangga, (Shabirah, 2020). Contoh lain usaha mikro yang ada di desa adalah apotek, toko alat tulis, salon, pusat perbelanjaan kecil, warung makan, laundry, usaha bercocok tanam, berkebun, bertenak, budi daya ikan, dan usaha kerajinan tangan (Tohir, 2020).

Semua jenis usaha mikro ini tentunya beresiko terhadap penularan Covid-19. Sehingga protokol kesehatan pada usaha mikro harus tetap menjadi perhatian kita semua guna memutus mata rantai penularan Covid-19. Mengingat belum ditemukannya vaksin untuk wabah Covid-19 maka hal yang bisa dilakukan yakni melakukan pemutusan rantai penularan dengan melakukan langkah-langkah penanggulangan terpadu termasuk keterlibatan seluruh kompenen masyarakat(Kemenkes, 2020a) .

Pada penelitian ini terdapat 53 pedagang usaha mikro yang bersedia menjadi responden dengan tempat usaha rawan tertular covid-19 yakni terletak di jalan poros lintas kabupaten. Salah satu upaya yang dapat dilakukan untuk meminimalisirkan resiko penularan Covid-19 yakni dengan menerapkan protokol kesehatan. Meskipun demikan sejauh ini belum ada protokol kesehatan yang secara spesifik terhadap pelaku usaha mikro di desa.

Protokol kesehatan berlaku bagi siapa saja yang terlibat atau berada di tempat dan fasilitas umum. Prinsipnya protokol kesehatan di tempat dan fasilitas umum harus memuat perlindungan kesehatan individu seperti memakai masker, cuci tangan dengan sabun, jaga jarak fisik dengan orang lain, dan meningkatkan daya tahan tubuh dengan perilaku hidup bersih dan sehat (PHBS). Adapun pada penelitian ini variabel yang berhubungan dengan penerapan protokol kesehatan pada pelaku usaha mikro yakni :

\section{Pengetahuan}

Pengetahuan seseorang terhadap objek mempunyai intensitas atau tingkat yang berbeda-beda mulai dari tahu (know), memahami (comprehension), aplikasi (application), analisis, syntesis, dan evaluasi. Dari pengalaman dan penelitian terbukti bahwa perilaku yang didasari oleh pengetahuan akan lebih bertahan lama dari pada perilaku yang tidak didasari oleh pengetahuan (Notoatmodjo, 2014). 
Hasil yang diperoleh menunjukkan ada hubungan antara pengetahuan dengan penerapan protokol kesehatan pada pelaku usaha mikro. Pengetahuan yang baik tentunya akan membuat pelaku usaha mikro menerapkan protokol kesehatan dengan baik pula.

\section{Sikap}

Sikap menggambarkan suka atau tidak suka seseorang terhadap suatu objek. Sikap sering diperoleh dari pengalaman sendiri atau dari orang lain yang paling dekat.Hasil penelitian menunjukkan ada hubungan antara sikap dengan penerapan protokol kesehatan pada pelaku usaha mikro.

Hasil penelitian ini sejalan dengan pendapat Notoatmodjo (2014) yang mengatakan bahwa sikap seseorang akan mempengaruhi tindakan seseorang. Terdapat 4 tingkatan dalam sikap yakni menerima, merespon, menghargai dan bertanggung jawab.

Menurut Azwar (2012) sikap berhubungan dengan hal-hal bagaimana individu berpresepsi terhadap suatu objek. Sikap merupakan perasaan yang menyangkut aspek emosional dan subjektifitas individu terhadap objek, baik yang positif (rasa senang) maupun negatif (rasa tidak senang).

\section{Perilaku Hidup Bersih dan Sehat (PHBS)}

Aspek perilaku merupakan hal yang paling penting agar terwujud status kesehatan masyarakat yang semakin meningkat. Agar terwujud kesehatan masyarakat yang meningkat maka seluruh anggota masyarakat, baik secara individu/pribadi, anggota keluarga, anggota dari lingkungan sekolah, lingkungan kerja, dan sebagainya harus hidup dalam lingkungan yang sehat, berperilaku hidup sehat, serta mampu menjangkau pelayanan kesehatan yang bermutu, adil dan merata serta memiliki derajat kesehatan yang setinggi-tingginya. Untuk mewujudkan peningkatan kesehatan masyarakat tersebut, maka pemerintah membuat suatu program yang dinamakan Prgaram PHBS atau Perilaku Hidup Bersih dan Sehat (Maryuani, 2013) .

Hasil Penelitian menunjukkan ada hubungan antara perilaku dengan penerapan protokol kesehatan pada pelaku usaha mikro. Kebiasaan pelaku usaha mikro melakukan PHBS rumah tangga tentunya akan memudahkan mereka untuk menerapkan protokol kesehatan. Salah satu contoh PHBS yang berhubungan dengan penerapan protokol kesehatan adalah cuci tangan pakai sabun (CPTS), bagi mereka yang terbiasa cuci tangan di rumah maka tidak akan canggung jika harus melakukannya setiap saat di toko.

\section{Ketersediaan Sarana dan Prasarana}

Meski selalu bergandengan sarana dan prasarana memiliki arti dan fungsi berbeda. Menurut Moenir (1992-119), mengatakan sarana adalah segala jenis peralatan, perlengkapan kerja dan fasilitas yang berfungsi sebagai alat utama atau pembantu dalam pelaksanaan pekerjaan, dan juga dalam rangka kepentingan yang sedang berhubungan dengan organisasi kerja. Dari pengertian sarana yg di katakan Moenir tersebut jelas memberi petunjuk sarana merupakan seperangkat alat yang digunakan dalam suatu proses kegiatan baik alat tersebut. Sementara prasarana adalah peralatan pembantu atau juga peralatan utama, dan kedua alat tersebut berfungsi untuk mewujudkan suatu tujuan yang ingin dicapai (Fatimah, 2019).

Hasil Penelitian menunjukkan ada hubungan antara ketersediaan sarana dan prasarana dengan penerapan protokol kesehatan pada pelaku usaha mikro. Sama halnya dengan penerapan protokol kesehatan pada pelaku UKM akan 
terlaksana dengan baik jika tersedia sarana dan prasarana yang mendukung. Misalnya disediakan tempat cuci tangan, sabun dan air bersih untuk mencuci tangan atau disediakan masker untuk digunakan selama beraktifitas.

Jaga jarak pada saat jual-beli dapat mengurangi resiko penularan Covid-19, sesuai dengan penelitian Shereen ddk (2020) yang mengemukakan bahwa penyebaran virus dari manusia ke manusia dapat terjadi karena melakukan kontak dekat dengan orang yang terinfeksi. Selain itu penelitian Shen dkk (2020) juga mengemukakan bahwa transmisi melalui udara berkontribusi terhadap wabah Covid19 sehingga perlu penggunaan masker saat beraktifitas di luar rumah. Sama halnya dengan penelitian Jahromi dkk (2020) yang mengemukakan pentimgnya menggunakan masker di tempat umum mengingat penyebaran Covid-19 sangat cepat dan banyak dari mereka yang terinfeksi tanpa gejala. Masker kain merupakan salah satu alternatif sederhana dan ekonimis, sebagai alat pencegahan di masyarakat (Esposito, et al, 2020).

Memakai masker adalah bagian protokol kesehatan. Masih banyak masyarakat yang belum menyadari tentang pentingnya masker. Selain itu, masyarakat belum semuanya mampu menyediakan masker dengan jumlah yang cukup (MediaIndonesia, 2020).

Untuk mengantisipasi penularan covid-19 ini pemerintah Kabupaten Gowa mengeluarkan Peraturan Daerah yang mewajibkan masyarakat menggunakan masker di luar rumah. Hal ini tentunya akan membuat masyarakat berupaya menyediakan masker sendiri.

\section{KESIMPULAN DAN SARAN}

Berdasarkan penelitian yang dilakukan dapat disimpulkan bahwa ada hubungan antara pengetahuan, sikap, PHBS dan Ketersediaan sarana dan prasarana dengan penerapan Protokol Kesehatan Pada Pelaku Usaha Mikro.

Penularan Covid-19 ini sangat cepat sehingga perlu diadakan edukasi kepada warga terkait penyebab penularan Covid-19 diantaranya tidak melakukan Perilaku Hidup Bersih dan Sehat (PHBS) atau Cuci Tangan Pakai Sabun(CTPS) dan faktor lingkungan.

\section{Referensi}

Agustina, D. (Producer). (2020). Sulsel Peringkat 4 Kasus Covid-19 Tertinggi di Indonesia, Menkes Hingga JK akan Kunjungi Makassar. Tribunnews.com. Retrieved from https://www.tribunnews.com/corona/2020/06/06/sulsel-peringkat-4-kasus-covid-19tertinggi-di-indonesia-menkes-hingga-jk-akan-kunjungi-makassar

Azwar. (2012). Metode Penelitian. Yogyakarta: Pustaka Belajar.

CDC. (2020). Coronavirus Disease 2019 (COVID-19). Centers For Disease Control and Prevention (CDC).

Dinkes. (2020). Kasus Covid-19 Kabupaten Gowa. from Dinas Kesehatan Kabupaten Gowa

Esposito, S., Principi, N., Leung, C,C., Migliori, G, B. Universal Use Of Face Masks For Success againts Covid-19: Evidence and Implications for Preventiion Policies. European Respiratory Journal 2020. DOI : 10.1183/ 13993003. 01260-2020 
Nismawati, Faktor Yang Berhubungan Dengan Penerapan Protokol Kesehatan

Fatimah, N. (2019). Pengertian Sarana dan Prasarana, Fungsi Hingga Contohnya.

Jahromi, K,M., Sulkowski, M., Naieni, H,K. Public Masking: An Urgent Need to Revise Global Policies to Protect against COVID-19. Am. J. Trop. Med. Hyg., 102(6), 2020, pp. 1160-1161. doi:10.4269/ajtmh.20-0305

Haris, R. (2017). Green Brand Characteristics For The Entrepreneurs. UNM Environmental Journals, 1(1), 23-27.

Kemenkes. (2020a). Pedoman Pemberdayaan Masyarakat Dalam Mencegah COVID-19 Di RT/RW/Desa. Jakarta: Kementrian Kesehatan Republik Indonesia.

Kemenkes. (2020b). Pedoman Pencegahan Dan Pengendalian Coronavirus Disease 2019 (Covid19): Kementrian Kesehatan Republik Indonesia.

Maryuani, A. (2013). Perilaku Hidup Bersih dan Sehat (PHBS). Jakarta: Trans Info Media.

MediaIndonesia (Producer). (2020, 15 Mei 2020). Kemenkop Ajak Pelaku UMKM dan Masyarakat Taat Protokol Kesehatan. Media Indonesia.com. Retrieved from https://mediaindonesia.com/read/detail/313231-kemenkopajak-pelaku-umkm-danmasyarakat-taat-protokol-kesehatan

Notoatmodjo. (2014). Ilmu Perilaku Kesehatan. Jakarta: Rineka Cipta.

Penyusun, T. (2020a). Buku Saku Desa Tangguh Covid - 19. Yogyakarta: Center For Tropical Medicine Universitas Gadjah Mada.

Penyusun, T. (2020b). Pedoman Umum Menghadapi Pandemi Covid-19 Bagi Pemerintah Daerah. Pencegahan, Pengendalian, Diagnosis dan Manajemen. Jakarta: Kementrian Dalam Negeri Republik Indonesia.

Razi, F., P, V. Y., Amani, S. A., \& Fauzia, J. H. (2020). Bunga Rampai Covid-19 : Buku Kesehatan Mandiri Untuk Sahabat \#DiRUMAHAJA. Depok: PD PROKAMI Kota Depok.

Shabirah, N. (Producer). (2020). Usaha Toko Kelontong. Retrieved from https://noorshabirah.wordpress.com/tip-trik-usaha-kecil/usaha-toko-kelontong/

Shereen, M.A., Khan, S., Kazmi, A., Bashir, N. \& Siddique, R. 2020, 'COVID-19 Infection: Origin, Transmission, and Characteristics of Human Coronaviruses', Journal of Advanced Research, Vol. 24, pp. 91-8.

Shen, Y., Li, C., Dong, H., Wang, Z., Martinez, L., Sun, Z., ... \& Wang, F. 2020, 'Airborne transmission of COVID-19: Epidemiologic Evidence from Two Outbreak Investigations.

Sulselprov. (2020). Sulsel Tanggap Covid-19. from https:// covid19.sulselprov.go.id/data

Sugiono. (2016). Metode Penelitian Kuantitatif, Kualitatif, dan R\&D. Bandung : Alfabeta

Tohir (Producer). (2020). 5 Jenis UKM Pedesaan yang Membantu Keuangan Masyarakatnya. Retrieved from https://www.folderbisnis.com/jenis-ukm-usaha-mikro-kecil-menengahpedesaan

WHO. (2020a). Coronavirus Health Topics. www.who.int/health-topics/coronavirus\#tab=tab_1: World Health Organization.

WHO. (2020b). Coronavirus Disease 2019 (COVID-19) Situation Report-67: World Health Organization. 
UNM Environmental Journals, Vol.3 No.3 Agustus 2020 hal. 116 - 124 